\title{
High sulfur solubility in hydrous felsic magma at coexistence of sulfide and sulfate
}

\author{
XingCheng LiU ${ }^{1}$, Ting XU ${ }^{1}$, XiaOlin XiOnG ${ }^{1}$ \\ ${ }^{1}$ State Key Laboratory of Isotope Geochemistry, Guangzhou \\ Institute of Geochemistry, Chinese Academy of Sciences, \\ Guangzhou 510640, China \\ (*correspondence: liuxingcheng@gig.ac.cn)
}

Porphyry deposits supply major proportion of the world's copper $(\mathrm{Cu})$ and gold $(\mathrm{Au})$. The role of magmatic sulfur $(\mathrm{S})$ is important in the ore-forming processes. On one hand, the giant deposits require abundant $\mathrm{S}$ in addition to metals. On the other hand, when $\mathrm{S}^{2-}$ exceeds its solubility at variable oxygen fugacity $\left(f \mathrm{O}_{2}\right)$ conditions, sulfide saturated, scavenging $\mathrm{Cu}$ and $\mathrm{Au}$ and resulting in metal depletion in the magma. It is believed that high $f \mathrm{O}_{2}$ depresses saturation of sulfide and favors the formation of porphry deposits. However, the relationship between oxidation state, S solubility and ore-forming process remains unclear. Here, we conducted experiments on a hydrous dacite at $1.0 \mathrm{GPa}$ and 850 to $950{ }^{\circ} \mathrm{C}$ using piston-cylinder press. The oxygen fugacity ranges from FMQ-1.3 to FMQ+4.8. The results show that the maximum $\mathrm{S}$ solubility in deep hydrous silicic magma occur at the middle $\mathrm{fO}_{2}(\sim \mathrm{FMQ}+2)$, where sulfide $\left(\mathrm{S}^{2-}\right)$ and sulfate $\left(\mathrm{S}^{6+}\right)$ coexist, and the solubility is up to over 6000 ppm, higher than the solubility of $\mathrm{S}^{2-}$ plus $\mathrm{S}^{6+}$. Based on the $\mathrm{S}$ and $\mathrm{Au}$ solubilities, we infer that an intermediate sulfur species, probably sulfite $\left(\mathrm{S}^{4+}\right)$, may be present in hydrous magma. $\mathrm{As} \mathrm{SO}_{2}$ is quite soluble in fluids, $\mathrm{S}^{4+}$ solubility in hydrous magmas increase with water content. Thus, the relatively high oxidation state and high $\mathrm{H}_{2} \mathrm{O}$ content in hydrous magmas in arc regions favor the presence of $\mathrm{S}^{4+}$. As water solubility increases with pressure, deep magmas can dissolve more water and $\mathrm{S}^{4+}$ than shallow magmas, which may explain why giant porphyry $\mathrm{Cu}-\mathrm{Au}$ deposits occured at thickened continental arcs. Our results also have important implications for understanding $\mathrm{S}$ flux from subducting slabs to the mantle wedge. 